\title{
Acute respiratory morbidity in late preterm infants
}

\author{
Simonetta Picone*, Roberto Aufieri, Piermichele Paolillo \\ From XX National Congress of the Italian Society of Neonatology \\ Rome, Italy. 9-11 October 2014
}

\section{Background}

Late preterm (LP) infants [gestational age (GA): 3436 weeks] are at increased risk of neonatal acute respiratory morbidity compared with term infants (GA: 37-41) $[1,2]$. The observed rate of acute respiratory morbidity, in a population of about 20,000 LP infants, was $10-12 \%$ vs $1.4 \%$ of term infants [1]. Transient tachypnea of the newborn (TTN) and respiratory distress syndrome (RDS) are the most common diagnosis, with RDS rate reaching $10.5 \%$ in infants born at 34 weeks of GA [1,2]. Major causes of respiratory morbidity in LP are: prematurity and birth by Cesarean Section (CS) $[1,3]$.

\section{Material and methods}

We retrospectively studied $830 \mathrm{LP}$ and moderate preterm (MP) infants (GA: 33-36 weeks) admitted to our unit from June 2009 to December 2013. Infants were classified according to GA: 33 weeks $(\mathrm{n}=129), 34$ weeks $(\mathrm{n}=176)$, 35 weeks $(\mathrm{n}=225), 36$ weeks $(\mathrm{n}=300)$. Clinical charts for each patient were reviewed and main diagnosis recorded.

\section{Results}

Twenty-six percent of LP/MP infants $(214 / 830)$ had an acute respiratory disorder. The most frequent diagnosis

Table 1 Acute respiratory morbidity in LP/MP infants $(n=830)$

\begin{tabular}{|c|c|c|c|c|c|}
\hline & & & $\begin{array}{c}\mathrm{GA}^{\mathrm{a}} \\
\text { (weeks) }\end{array}$ & & \\
\hline & 33 & 34 & 35 & 36 & TOT \\
\hline$n$ & 129 & 176 & 225 & 300 & 830 \\
\hline Respiratory morbidity & $60(46.5)$ & $53(30.1)$ & $42(18.7)$ & $59(19.7)$ & $214(25.8)$ \\
\hline$\overline{T T N^{\mathbf{b}} \mathrm{n}(\%)}$ & $14(10.9)$ & $15(8.5)$ & $16(7.1)$ & $30(10.0)$ & $75(9.0)$ \\
\hline $\mathbf{R F}^{\mathbf{c}} \mathrm{n}(\%)$ & $31(24.0)$ & $14(8.0)$ & $12(5.3)$ & $8(2.7)$ & $65(7.8)$ \\
\hline RDS $^{\mathbf{d}} \mathrm{n}(\%)$ & $12(9.3)$ & $24(13.6)$ & $12(5.3)$ & $14(4.7)$ & $62(7.5)$ \\
\hline $\mathrm{PNX}^{\mathbf{e}} \mathrm{n}(\%)$ & $1(0.8)$ & - & $8(3.5)$ & $7(2.3)$ & $16(1.9)$ \\
\hline Pneumonia n (\%) & $1(0.8)$ & $3(1.7)$ & $1(0.4)$ & $8(2.7)$ & $13(1.6)$ \\
\hline $\operatorname{AOP}^{\mathbf{f}} \mathrm{n}(\%)$ & $3(2.3)$ & - & - & $2(0.7)$ & $5(0.6)$ \\
\hline $\mathbf{P P H}^{\mathbf{9}} \mathrm{n}(\%)$ & - & $1(0.6)$ & $1(0.4)$ & - & $2(0.2)$ \\
\hline MAS $^{\mathbf{h}}$ n (\%) & - & - & - & - & - \\
\hline Infection in infants with RDS n (\%) & $3(25.0)$ & $9(37.5)$ & $6(50.0)$ & $9^{*}(64.3)$ & $27^{*}(43.5)$ \\
\hline Infection in infants with other respiratory morbidity $\mathrm{n}(\%)$ & $8(16.7)$ & $10(34.5)$ & $11(39.7)$ & $14^{*}(31.1)$ & $43^{*}(28.3)$ \\
\hline
\end{tabular}

* Correspondence: simpico@libero.it

Division of Neonatology and Neonatal Intensive Care, Department of

Maternal and Child Health, Casilino General Hospital, Roma, Italy 
were: $\operatorname{TTN}(\mathrm{n}=75 ; 9.0 \%)$; respiratory failure (RF) $(\mathrm{n}=$ $65 ; 7.8 \%)$ and RDS ( $\mathrm{n}=62 ; 7.5 \%)$; pneumothorax / pneumomediastinum $(\mathrm{n}=16 ; 1.9 \%)$; pneumonia $(\mathrm{n}=13$; $1.6 \%)$; apnea of prematurity $(\mathrm{n}=5 ; 0.6 \%)$; persistent pulmonary hypertension $(\mathrm{n}=2 ; 0.2 \%)$. All the 62 infants with RDS were intubated, required mechanical ventilation (1-4 days) and surfactant administration (1-4 doses). The forty-three percent of infants with RDS also had a concomitant diagnosis of infections. The infection rate in infants with RDS was significantly higher than that in other respiratory morbidities $(\mathrm{p}<0.05)$. Complete results are reported in Table 1 . Of the 62 cases of RDS reported: 60 resolved and 2 deceased (one patient with necrotizing enterocolitis, one patient with disseminated intravascular coagulation).

\section{Conclusions}

Acute respiratory morbidity in our unit affects a quarter of LP/MP infants. An important percentage (7.5\%) is represented by RDS, that is often associated with infection. Infants born at 34 weeks of GA are the population at higher risk of RDS. Even if rate and severity of acute respiratory morbidity in LP are already described by a number of epidemiological studies, further investigation is needed to better clarify the optimal timing and dose of surfactant administration and to correlate different strategies of respiratory management with long-term respiratory and neurological outcomes. The high infection rate found among infants with RDS and acute respiratory morbidity, emphasizes the importance of a prompt diagnosis and treatment of chorioamnionitis and perinatal infections.

Published: 9 October 2014

\section{References}

1. Hibbard JU, Wilkins I, Sun L, Consortium of Safe Labor: Respiratory morbidity in late preterm births. JAMA 2010, 304:419-425.

2. Ashley Darcy M, Lucky J: Respiratory disorders in moderately preterm, late preterm and early term infants. Clin Perinatol 2013, 40:665-678.

3. Natile $M$, Ventura ML, Colombo M, Bernasconi D, Locatelli A, Plevani C, Valsecchi MG, Tagliabue P: Short-term respiratory outcomes in late preterm infants. Ital J Pediatr 2014, 40:52.

doi:10.1186/1824-7288-40-S2-A34

Cite this article as: Picone et al:. Acute respiratory morbidity in late preterm infants. Italian Journal of Pediatrics 2014 40(Suppl 2):A34.

\section{Submit your next manuscript to BioMed Central} and take full advantage of:

- Convenient online submission

- Thorough peer review

- No space constraints or color figure charges

- Immediate publication on acceptance

- Inclusion in PubMed, CAS, Scopus and Google Scholar

- Research which is freely available for redistribution

Submit your manuscript at www.biomedcentral.com/submit
C Biomed Central 